\title{
通年性鼻アレルギー減感作療法の遠隔成績
}

\author{
大塚 博邦・大西 正樹・谷本 秀司 \\ 目沢 朗憲・市川 菊乃・大久保公裕 \\ 関 はるみ・池田 雅一・馬場 俊吉 \\ 森園 徹志・奥田 稔
}

\section{Long Term Effect of Immunotherapy for Perennial Nasal Allergy}

\author{
Hirokuni Otsuka, Masaki Ohnishi, Hideji Tanimoto, \\ Akinori Mezawa, Kikuno Ichikawa, Kimihiro Okubo, \\ Harumi Seki, Masakazu Ikeda, Shunkichi Baba, \\ Tetushi Morizono and Minoru Okuda \\ (Nippon Medical School)
}

From 1980 to 1985,678 patients with nasal allergy were found to have perennial sensitivity to house dust at the ENT clinic of Nippon Medical School. These patients were divided into two groups, one was treated with immunotherapy until May 1987. Questionnair were mailed to all the patients asking about severity of nasal symptoms at the time of the first visit and after immunotherapy, and whether or not they were being treated with other methods at the present time.

Answers were received from 235 patients. Improvement was noted in $40 \%$ of the patients after 6 months, in 52\% after $7 \sim 12$ months, in $61 \%$ after $13 \sim 24$ months, in $64 \%$ after 25 36 months, in $81 \%$ after 37 months or more of the immunotherapy. Of the 87 patients in the non-immunotherapy group 56\% improved, but more of these patients had milder symptoms than did those treated with immunotherapy. There was a statistically significant difference in improvement between the immunotherapy group for more than 37 months and the non-immunotherapy. Treatment with other drugs is still needed in $51 \%$ of the patients who did not have immunotherapy, in $40 \%$ of those with immunotherapy for less than 6 months, in 39\% of those with $7 \sim 12$ months, in $33 \%$ of those with $13 \sim 24$ months, in $16 \%$ of those with $25 \sim 36$ months, in $18 \%$ of those with over 37 months of immunotherapy.

Key words : immunotherapy, nasal allergy house dust, long term effect

$$
\text { はじめに }
$$

鼻アレルギーに対する減感作療法は根本的療 法に近いものとされている。 それは現在の薬物
療法では得られない感作状態から脱する効果を 得るととを意味している1). 本邦における鼻ア レルギーの発症抗原である house dust (HD) 
アレルギーに対する減感作療法の有効率は60～ $70 \%$ と報告されているが，鼻アレルギーは自然 寛解もあるのでこれらの減感作の効果を疑問視 するものもいる，そこで今回我々は1980年より 1985年の 6 年間に日本医科大学耳鼻咽喉科アレ ルギー外来を受診しアレルギー検査より HD を主抗原とする非季節性鼻アレルギーと診断し た患者 678 名に対し，治療中の経過を観察し， アンケート調査をおてなって減感作療法の有無, 治療期間により遠隔成績にどのような違いが生 じるのかを解析した。

\section{対象と方法}

\section{1. 対 象}

対象は 1980 年より 1985 年の 6 年間に日本医科 大学耳鼻咽喉科アレルギー外来で HD を主と する通年性鼻アレルギーと診断され, 減感作非 施行の者，または減感作を受けたが，1987年 5 月までに減感作治療を中止した者計 678 名であ る. 男女比は391対 $287, \mathrm{HD}$ 単独感作例は388例 であり，HD+スギ感作例は131例，HD+他花 粉は49例, $\mathrm{HD}+$ ×ギ+他花粉は49例, $\mathrm{HD}+$ 真 菌は31例であり，他の30例む HD を中心とし たアレルギーであった．いずれあ症状は通年性 であり，症状に季節性のあるあのは除外した。 また花粉による鼻誘発反応は陰性のものがほと んどであり，陽性であっても問診より季節性の ないむのは対象とした。 てれらの患者の減感作 の状況をみると，減感作非施行群は283 例であ り, 減感作 6 力月以下 100 例, 7 〜2力月は 65 例，13〜24力月は96例，25〜36力月は63例，37 〜60力月は50例，61力月以上は21例であった。

\section{2. 減感作の方法}

減感作を HD 抗原液 (鳥居製) の閾值濃度又 は閾値10倍希釈濃度の $0.03 \mathrm{ml}$ よりはじめ，50 \%増量で週 2 回皮内又は皮下に注射し, $0.5 \mathrm{ml}$ に達するとさらに10倍高濃度の抗原液 $0.05 \mathrm{ml}$ より同様に注射を㧍てない，乙れを $3 \sim 4$ 力月 続けた後最終濃度の $0.5 \mathrm{ml}$ で週に 1 度を 4 回, 2 週に 1 度を 4 回行ない, 後 1 力月に 1 度で維 持した．抗原の種類は殆どが $\mathrm{HD}$ であるが，
真菌類アレルギーではこれを併用した.

3. アンケート調査

アンケート調査は減感作非施行群と施行群の 両者に郵便で行なった。减感作非施行群に対し ては，1）当科での鼻アレルギー検査から現在 に至るまでの症状の変化，2）現在の鼻アレル ギー症状のための治療の有無，3）そして現在 の治療内容の 3 点を聞き, 減感作施行群には,

1 ) 当科での減感作中止の理由，2）減感作中 止時の症状の改善，3）减感作中止時加ら現在 に至るまでの症状の変化，4）現在の鼻アレル ギーの治療の有無，5）その治療内容を聞いた.

4. 臨床症状と鼻誘発反応の評価

鼻アレルギー症状と鼻誘発反応の程度は奥田 に因る分類を用い ${ }^{21}$ ，減感作前，減感作中そし て各患者の減感作終了時の鼻アレルギー症状の 程度と HD による鼻誘発反応の程度を調査し た.

\section{5. 統計学的検定}

各群における鼻症状と鼻誘発反応の程度の比 較は群間における各スコアーに分布する症例数 を $\chi^{2}$ 一検定を用いて行なった。

\section{結果}

1. 減感作中の臨床症状と鼻誘発反応の変化 アンケートとは別に，减感作を25力月以上行 なったHD 単独感作群 79 例と 13 力月以上行なっ たHD+スギ感作群58例の減感作前，減感作開 始後 6 力月， 1 年， 2 年， 3 年目の鼻症状之鼻 誘発反応の程度の変化を図 1 亿示した. HD 単 独感作群では減感作 6 力月以降は減感作前に比 べ有意の差 $(p<0.01)$ で症状の改善が見られた. 同群の減感作による鼻誘発反応の変動をみると, 鼻症状と同様 6 力月以降で改善がみられた $(\mathrm{p}<$ 0. 05).

一方 $\mathrm{HD}+$ ×ギ感作群に於ける鼻症状の変化 屯同様に 6 カ月以降で改善し，また HD によ る鼻誘発反応は 1 年以降で低下がみられた $(\mathrm{p}<$ 0. 01).

2. アンケート回収率

アンケートの回収は678例中235例(34.6\%)で 


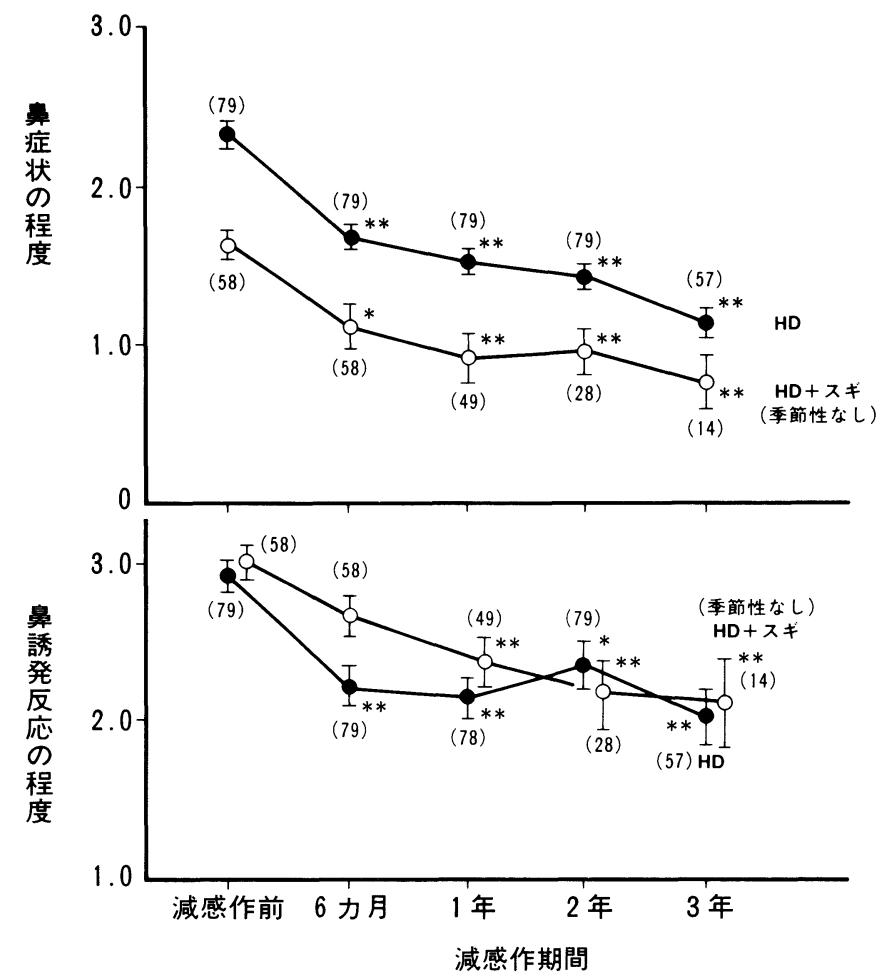

図 1 通年性鼻アレルギーにおける減感作中の鼻症状と鼻誘発反応の変化. $x^{2}$-test で減感作前に比し有意差あり, $\mathrm{p}<0.05(*), \mathrm{p}<0.01(* *)$.

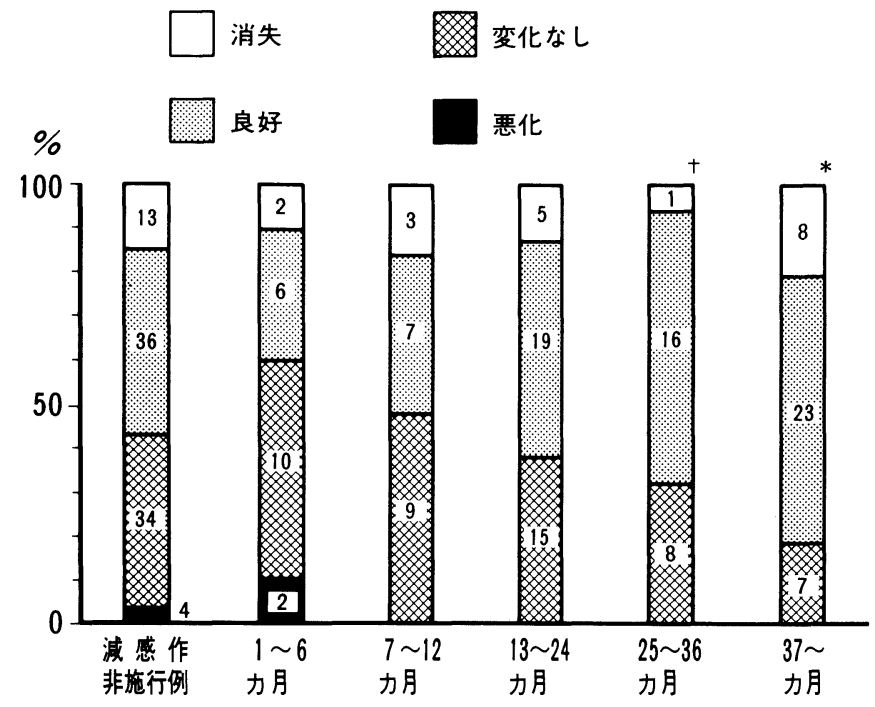
(n) (87)
(20)
(19)
(39)
(25)
(38)

\section{減感作施行例（期間別）}

図 2 通年性鼻アレルギーの減感作非施行群の現在の症状と, 減感作群施行期間 別における症状の変化. いずれもアンケートによる。 †は減感作非施行群 より有意差の傾向 $(\mathrm{p}<0.1), *$ は有意差 $(\mathrm{p}<0.05)$ があった. 
あった。 その内訳は減感作非施行例87例，施行 例148例で 24 力月以下 80 例, 25 力月以上 68 例で あった。

3. アンケートの結果

1 ）治療中止の理由

アンケートによって減感作中止の理由に対す る解答を得たのは 144 例であった。 ての内減感 作期間 24 力月以内で中止した80例中 34 例 (42\%) が忙しいためと答え，次いで症状が良くなった から自己判断で止めた15例(18\%)，他院にかか った 8 例 (1.0\%)，症状が良くならない 8 例 $(10$ \%)，症状が良くなったので止めても良いとい われた 6 例 $(7 \%)$ となっている.

2 ) 减感作非施行群, 施行群の患者背景

減感作非施行, 施行の選択は患者自身の意志 によるものが殆どであった．アンケートの質問 に答えた患者の中で減感作非施行群と施行群 1 〜 6 力月, 7 ～12 力月, 13〜24力月, 25〜36力月, 36力月以上との間の年齢, 性別, 鼻症状の重症 度そして HD 抗原 disk による鼻誘発反応の程 度を表 1 にした。この結果，各群間に执いて年 秢, 性別, 鼻症状の強さに片よりは見られなか ったが，減感作 7 〜 12 月群においてのみ鼻誘 発反応の程度で強陽性（卅）の例が，他群より
多かった（表1）。また皮膚反応から HD のみ または HD+スギ花粉感作群(季節性無し)の患 者において同様に群間比較を行なったが有意差 はなかった。

3 ) 減感作中止時と現在の症状

図 2 はアンケートによる減感作非施行群の初 診時から現在に至るまでの症状経過と減感作群 に打ける減感作中止時の症状の変化を示す，減 感作非施行群で解答のあった87例において，現 在の鼻症状が消失または良くなった之答えたも のは49例（56\%）であり，減感作施行群におい ては良好，症状消失は減感作 6 力月までの 20 例 中 8 例 $(40 \%), 7$ 〜 12 月の 19 例中 10 例（52 $\%) ， 13 \sim 24$ 力月の 39 例中 24 例 $(61 \%), 25 \sim 36$ 力月の 25 例中 16 例 $(64 \%) ， 37$ 力以上の 38 例で は31例 (81\%) であった。統計学的検討では減 感作非施行群に比し24力月までは有意差は無か ったが，25力月以上で改善傾向があり $(\mathrm{p}<0.1)$ ， 36 力月以上で有意の差で $(p<0.05)$ 改善が多か った。 また $\mathrm{HD}$ 単独と $\mathrm{HD}+$ 十ギ感作群（季 節性なし)における現在の症状の変化をみると， 減感作非施行群と施行群との間には 25 力月以降 で施行群に改善のものが多く $(\mathrm{p}<0.05)$ みられ た（図 3 ）.

表 1 減感作非施・施行群（アンケート回収）の患者背景

\begin{tabular}{|c|c|c|c|c|c|c|c|c|}
\hline & & \multirow{2}{*}{ 非施行群 } & \multicolumn{5}{|c|}{ 施 行 群（期間別・月） } & \multirow{2}{*}{$\chi^{2}$-test } \\
\hline & & & $1 \sim 6$ & $7 \sim 12$ & $13 \sim 24$ & $25 \sim 36$ & $37 \sim$ & \\
\hline \multirow{2}{*}{ 年 } & $4 \sim 10$ & 29 & 3 & 6 & 11 & 10 & 11 & \multirow{5}{*}{ NS } \\
\hline & $11 \sim 20$ & 23 & 4 & 5 & 12 & 7 & 13 & \\
\hline 䅻 & $21 \sim 40$ & 21 & 9 & 8 & 10 & 6 & 10 & \\
\hline \multirow{2}{*}{ 歳 } & $41 \sim 60$ & 12 & 2 & 0 & 3 & 2 & 3 & \\
\hline & $61 \sim$ & 2 & 2 & 0 & 3 & 0 & 1 & \\
\hline & 男 & 47 & 14 & 9 & 22 & 14 & 23 & \multirow{2}{*}{ NS } \\
\hline & 女 & 40 & 6 & 10 & 17 & 11 & 15 & \\
\hline \multirow{3}{*}{ 鼻 } & 軽 & 23 & 3 & 2 & 5 & 4 & 6 & \multirow{3}{*}{ NS } \\
\hline & 中 & 33 & 7 & 9 & 17 & 16 & 12 & \\
\hline & 重 & 31 & 10 & 8 & 17 & 5 & 20 & \\
\hline \multirow{3}{*}{$\begin{array}{l}\text { 齄 } \\
\text { 発 } \\
\text { 応 } \\
\text { 応 }\end{array}$} & + & 19 & 6 & 3 & 8 & 7 & 6 & \multirow{3}{*}{$\begin{array}{l}7 \text { ～12力月の群 } \\
\text { で非施行群より } \\
\text { 強陽性例が多い } \\
(\mathrm{p}<0.05)\end{array}$} \\
\hline & H & 41 & 9 & 5 & 17 & 10 & 19 & \\
\hline & m & 18 & 5 & 10 & 12 & 6 & 8 & \\
\hline
\end{tabular}


4）減感作中止後における治療状況

アンヶート調査による現在の治療状況をみる と現在治療をうけている又は短期間受けていた を含めたものは，減感作非施行群で51\%，減感 作期間 1 〜 6 力群では40\%， 7 〜2力月群で
39\%，13〜24力月群で33\%，25３6力月群で16 \%，37カ月以上群で18\%であり，減感作非施行 群化比し減感作 $1 \sim 6$ 力月， 7 ～12力月，13〜 24力月の群では差がなかったが, 25〜36力月, 37 カ月以上群との間には有意差 $(\mathrm{p}<0.01)$ があり，

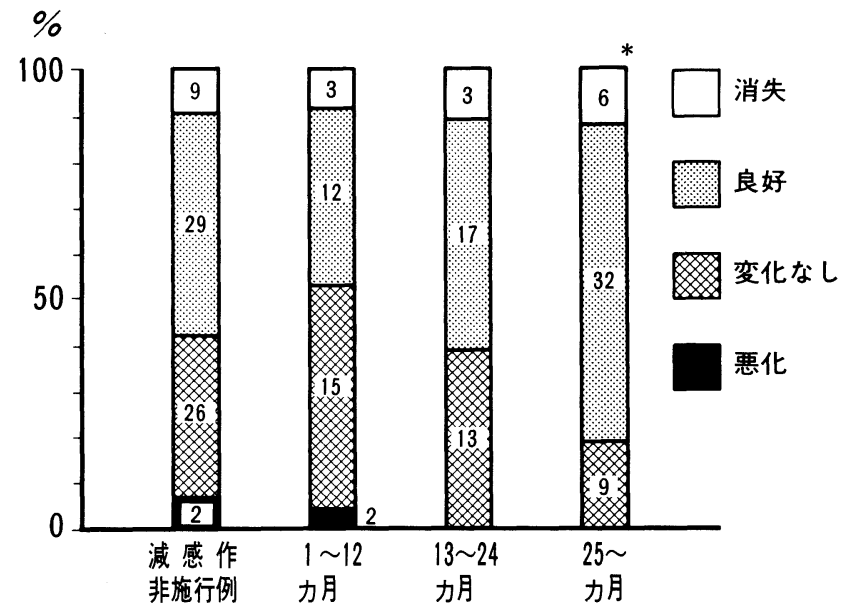

$\begin{array}{llll}\text { (n ) } & (66) \quad(32) \quad \text { (33) }\end{array}$

減感作施行例（期間別）

図 $3 \mathrm{HD}$ 感作群と $\mathrm{HD}+$ スギ感作群 (季節性なし) の減感作非施行例と, 施行例期間別における現在の鼻症状（アンケートによる）.

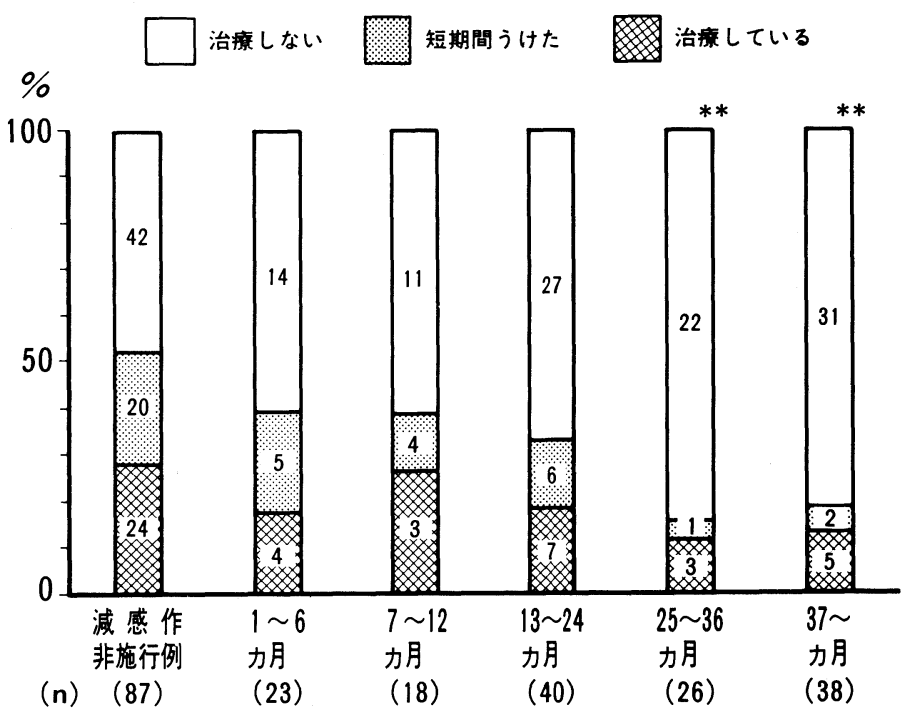

減感作施行例（期間別）

図 4 減感作非施行例と減感作施行例の現在の治療状況. 減感作非施行例に 比し，有意の差 $(* *: \mathrm{p}<0.01)$ があった. 
減感作非施行群より屯 25 力月上の減感作群で 治療を受けている人の率が少なかった（図 4).

5 ) 減感作有効群の再発率

25 カ月以上の減感作群でアンケートで減感作 終了後の症状に関する解答を得たのは68例であ り，乙のうち減感作により鼻症状が消失又は良 好であったと答えたのは54例 (79\%)であった。 この54例の減感作中止後の経過をみた。减感作 終了後現在まで 5 年以上経過した 15 例のうち軽 度悪化したものは 1 例であり, 減感作開始前の 程度にまで悪化したものはなかった。また 3 4 年経過した 27 例のうち軽度悪化したものは 5 例，悪化したのは 3 例であった。 そして減感作 終了後 2 年経過した 12 例中軽度悪化は 2 例あり, 悪化例はなかった。したがって再発するものの 多くは 4 年以内であり, 軽度悪化の頻度は 14.8 $\%$ (54例中 8 例), 悪化の頻度は7.1\%（42例中 3 例) であった. このととから HDを中心と する25力月以上の減感作の改善率は約 $80 \%$ であ り，再発は軽度悪化は 7 人に 1 人，悪化は 14 人 に 1 人の割合で起とり，しかもこれらは 4 年以 内に発生するが， 5 年を経ぎれば再発はほとん どないと考えられた。

\section{考 察}

減感作療法は20世紀の初期にアレルギーの 治療法として初めて用いられた ${ }^{3)} .1960$ 年から 1970年にかけて米国でこの治療効果を明らか にするため主にブタクサ花粉症を対象にした 二重盲検法による調査が行なわれた ${ }^{45)}$. この結 果多くの調査で抗原を用いた減感作群が対照を 用いた群に比べ有意差があるとの報告が圧倒的 に優位をしめた6)。本邦に扮いては二重盲検試 験は行なわれていないが HD 鼻アレルギーで

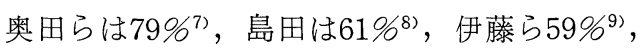
高原らは69\% $\%^{10)}$ の有効率を報告している。 しか しこれらの調查は同時期に受診した減感作非施 行例との比較を行なっていない. 今回の調査で は HD を主抗原とする通年性の症例を患者力 ルテより検討し，減感作期間が長くなるものほ ど症状の改善度が上がり，また鼻誘発反応の程
度も低下した。 さらに当科の治療から離れた患 者のアンケートによる調査では減感作非施行群 の現在と減感作 2 年以内の群における終了時の 症状の間には有意の差はみられなかったが，減 感作 2 年以上の群との間には有意の差があった。 また現在他院での治療状況をみても，現在治療 を受けている又は一時治療を受けていたを含め ると, 減感作非施行群では鼻アレルギー症状の 程度が施行群に比し軽度のあのが多かったにも かかわらず51\%が薬物，ネブライザーなどの治 療を受けていたのに対し，施行群では減感作 24 カ月までは30〜 40\%，25力月以上では $20 \%$ 力下 であり，減感作 25 力以上の屯のは減感作非施 行例より屯有意の差で鼻アレルギー症状のため に治療を受けているものは少なかった。このて とは減感作は患者が医師の手を離れる可能性を あった治療といえる。

減感作の効果発現の機序については, 種々の

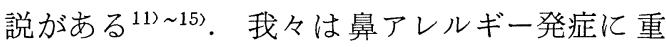
要な鼻粘膜表層のマスト細胞や好塩基球の数が 減少することを報告した ${ }^{16)}$ 。乙れらの細胞数の 多少が鼻症状の強弱之強い関係があり，しかも 減感作治療で有効群と無効群との間には局所マ ス卜細胞，好塩基球数の減少の程度に差がある ことから，乙れら好塩基性細胞の減少が減感作 療法による症状改善を説明する上で重要である と考えた.

近年多くのマスト細胞の stabilizer が開発さ れ，現在アレルギーの治療に用いられている.

これらの抗アレルギー剤や局所ステロイド剂な ごは鼻アレルギー患者の症状の改善に効果があ り，以前より治療しやすくなった感がする17).

しかし，薬物治療は一時的にアレルギー反応を 抑制するが薬物の投与を中止すれば再発する.

これに対し減感作療法は薬物療法より屯効果発 現に時間がかかり，長期の持続的治療の必要が ある欠点は否めないが，25力月以上の減感作に より，一度効果が得られると持続し，减感作終 了後も再発率は低いととは強調されねばならな い. 減感作後の再発率を具体的に云うと軽度悪 
化が 7 人に 1 人，悪化が 14 人に 1 人の頻度であ った。 またてれらの再発例の殆どは減感作終了 後 4 年以内に発現し，乙れを過ぎれば再発は殆 どみられなかった，今回行なった調査で通年性 アレルギー患者678例の減感作治療の施行率が 当初 395 例 $58.2 \%$ であったが, 25 力月以上になる と 134例19.7\%に減少した，中止の理由をみる

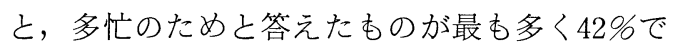
あり，減感作の維持のためにでさえ 1 力月に一 度の受診も出来ないと云った状況は今日の社会 情勢を反映していると考えられ，乙れからの対 処を考えなければならない。

\section{文献}

1) Mosbech $\mathrm{H}$ and Osterballe $\mathrm{O}$ : Does the effect of immunotherapy last after termination of treatment? Allergy $43: 523 \sim 529,1988$.

2) 奥田 稔: 鼻アレルギー. 263〜266頁, 金原出 版, 東京, 1988 .

3) Noon L : Prophylactic inoculation against hay fever. Lancet $1:$ 1572 1573, 1911.

4) Lichtenstein L, Norman P and Winkenwerder $\mathrm{W}$ : Clinical and in vitro studies on the role of immunotherapy in ragweed hay fever. Am J Med $44: 514 \sim 524,1968$.

5 ) Norman P, Winkenwerder $\mathrm{W}$ and Lichtenstein $\mathrm{L}:$ Maintenance immunotherapy in ragweed hay fever; booster injections at six week intervals. J Allergy $47:$ 273 283, 1971.

6) Patterson R, Lieberman P, Irons J, et al : Immunotherapy. Allergy (ed by Middleton Jr E, Reed $\mathrm{CE}$ and Ellis EF). pp 877 898, Mosby Co, St Louis, 1978.

7) 奥田 稔, 宇佐神篤, 打越 進, 他: 鼻アレルギ 一免疫療法の遠隔成績. 耳展 $21: 144 \sim 147,1978$.

8) 島田哲夫：特異的減感作療法. 耳鼻臨床 $70: 552$
〜555, 1978.

9 ）伊藤由紀子, 坂倉康夫, 鵜飼幸太郎, 他：当教室 における鼻アレルギー減感作療法の遠隔成績. 耳 鼻臨床 $74: 948 \sim 958,1981$.

10）高原哲夫, 藤谷哲造, 森本大和：鼻アレルギー減 感作療法の遠隔成績. 耳鼻 $29 ： 373 \sim 377,1983$.

11) Lichtenstein LM, Ishizaka $K$, Norman PS, et al: $\operatorname{IgE}$ antibody measurements in ragweed hay fever ; relationship to clinical severity and the results of immunotherapy. J Clin Invest $52: 472 \sim 482$, 1973.

12) Pruzansky JJ and Patterson R : Histamine release from leukocytes of hypersensitive individuals ; II reduction sensitivity of leukocytes after injection therapy. J Allergy 39:44〜50, 1967.

13）斎藤 紘：気管支喘息におりる試験管内ヒスタミ ン遊離試験に関する研究. アレルギー $22 ： 745 \sim$ 756, 1973.

14) Scully $M$ and Rackemann F : Studies on the blocking antibody of cooke in treatment of hay fever. J Allergy $12:$ 549 558, 1941.

15) Lichtenstein LM, Holtzman NA and Burnett LS : A quantitative in vitro study of the chromatographic ditribution and immunoglobulin characteristics of human blocking antibody. J Immunology $101:$ 317 324, 1968.

16）大塚博邦, 大西正樹, 目沢朗憲, 他 : 減感作によ 万鼻粘膜好塩基性細胞の変動. 耳鼻臨床 81 ： 1617〜1622, 1988.

17）大塚博邦：アレルギー用剂の現状と近未来の展望. 耳喉頭頸 $61 ： 493 \sim 497,1989$.

$\left(\begin{array}{l}\text { 原稿受付 : 平成元年 } 11 \text { 月 } 30 \text { 日 } \\ \text { 原稿採択 : 平成 } 2 \text { 年 } 1 \text { 月 } 17 \text { 日 } \\ \text { 別刷請求先 : 大塚博邦 } \\ \text { 干1113 東京都文京区干駄木 } 1-1-5 \\ \text { 日本医科大学耳鼻咽喉科学教室 }\end{array}\right)$

